\title{
Some generalizations based on stratification and vertical mixing in meromictic Lake Shira, Russia, in the period 2002-2009
}

\author{
D. Y. Rogozin - S. N. Genova • R. D. Gulati • \\ A. G. Degermendzhy
}

Received: 20 May 2009/Accepted: 20 May 2010/Published online: 5 June 2010

(C) The Author(s) 2010. This article is published with open access at Springerlink.com

\begin{abstract}
In a brackish, temperate, 24-m-deep Lake Shira, the profiles of salinity, temperature, oxygen and sulfide concentrations were measured on a seasonal basis from 2002 to 2009. The lake was shown to be meromictic with autumnal overturn restricted to mixolimnion. The depth of mixolimnion and position of oxic-anoxic interface varied annually. The spring mixing processes contribute to the formation of mixolimnion in autumn. The exceptionally windy spring of 2007 caused the deepening of mixolimnion in the winter of 2008. The winter position of oxic-anoxic interface was affected by the position of lower boundary of mixolimnion in all
\end{abstract}

Handling Editor: W. Mooij.

D. Y. Rogozin $(\varangle) \cdot$ A. G. Degermendzhy

Institute of Biophysics of Siberian Branch of Russian

Academy of Sciences, Akademgorodok 50-50, 660036

Krasnoyarsk, Russia

e-mail: rogozin@ibp.ru

D. Y. Rogozin · A. G. Degermendzhy

Siberian Federal University, Svobodny 79, 660071

Krasnoyarsk, Russia

S. N. Genova

Institute of Computational Modeling of Siberian Branch of Russian Academy of Sciences, Akademgorodok 50-50, 660036 Krasnoyarsk, Russia

R. D. Gulati

The Netherlands Institute of Ecology, Center for Aquatic Ecology, Nieuwersluis, The Netherlands winters. The salinity in the winter mixolimnion increased compared with the autumn because of freezing out of salts from the upper water layers meters during ice formation and their dissolution in water below. The profiles of salinity and temperature were simulated by the mathematical 1-D model of temperature and salinity conditions taking into account ice formation. The simulated profiles generally coincided with the measured ones. The coincidence implies that simplified one-dimensional model can be applied to roughly describe salinity and density profiles and mixing behavior of Lake Shira.

Keywords Meromixis - Mixolimnion Oxic-anoxic interface Thermocline . Weather conditions $\cdot 1-\mathrm{D}$ model

\section{Introduction}

Meromixis is a condition of persistent chemical stratification in lakes with incomplete mixing over the course of a year. It usually results in anoxia and the accumulation of nutrients in the monimolimnion (deeper water layers up to lake bottom) and reduced vertical mixing (Romero and Melack 1996). Numerous saline lakes worldwide are known to be meromictic (Boehrer and Schulze 2008). Many works explore different aspects of the ecology and limnology of meromictic lakes. These lakes are interesting objects for research for several reasons. 
First of all, they are good model systems for microbial ecology research because of high physical stability of the water masses, clearly separated compartments and relatively constant vertical stratification in bacterial populations together with many physiochemical parameters in such lakes. A compact transition zone between the oxic mixolimnion (mixed water layers) and anoxic monimolimnion in many cases is populated by a dense microbial community dominated by anoxic phototrophic bacteria (Sorokin 1970; Van Gemerden and Mas 1995; Rogozin et al. 2010). Microbial interactions in this community, as well as the role of anoxic phototrophic bacteria in lake trophic chains have remained understudied (Overmann 1997).

Secondly, some lakes that are subject to waterlevel fluctuations tend to experience transitions from meromixis to holomixis (complete vertical mixing) or the other way round. Such changes lead to qualitative changes in the structure of plankton communities, and these changes need to be predicted for water quality prognoses. For example, during transition from a meromictic to a holomictic state in Lake Mono (California, USA), nutrient concentrations in the mixolimnion increased, resulting in a noticeable increase in primary productivity, chlorophyll concentration and zooplankton population (Melack and Jellison 1998). Significant changes in the ecosystems of meromictic lakes can also be caused by partial disturbance of stratification, i.e., chemocline "disruption". For example, in Lake Cadagno (Switzerland), the disruption of chemocline caused an increase in phytoplankton biomass, which, in its turn, increased the turbidity in the mixolimnion. Consequently, the species composition of the dominant anoxic phototrophic bacteria in the chemocline changed (Tonolla et al. 2005). In Lake Lugano, unusually deep mixing events resulted in 10- to 20 fold increase in phytoplankton density and affected the lake's trophic status because an additional amount of nutrients was carried upwards to the euphotic zone (Simona 2003).

Thirdly, meromictic lakes arouse interest because their bottom sediments are good natural "archives", due to (1) the stable stratification of bottom water that reduces sediment resuspension; (2) presence of hydrogen sulfide prevents bioturbation and leads to absence of benthic invertebrates. Therefore, the initial sequence of sediment layers is well conserved in meromictic lakes and can be "deciphered" using physical-chemical and molecular methods. Particularly in paleolimnological studies, carotenoids of phototrophic bacteria may serve as a sensitive measure of past biomass changes and as indicators of meromictic periods in the lake's history (Overmann et al. 1993; Brocks and Schaeffer 2008).

For the vast Asian part of Russia (Siberia and Far East), there are only three saline lakes described in literature as meromictic. These are Shira, Shunet (Khakassia) and Doroninskoye (Trans-Baikal region) lakes (Rogozin et al. 2009; Zamana and Borzenko 2007). Lake Shira is a promising object for studying from different the above-mentioned perspectives. Although Lake Shira has been intensively investigated during the last decade (Degermendzhy et al. 2002; Rogozin et al. 2005, 2009; and many others), the mixing behavior and long-term annual dynamics of physical-chemical stratification, as well as the effect of weather conditions on year-to-year variation of the lake stratification, have not been reported so far.

It was shown earlier that the chemocline zone in this lake is not located at a fixed depth, but varies annually, especially during under-ice periods (Rogozin et al. 2009). Thus, anoxic phototrophic bacteria populating the chemocline get into more favorable light conditions when the chemocline is located at a "shallower" depth, and vice versa. Therefore, prediction of stratification is important, particularly, for understanding the dynamics of anoxic phototrophic bacteria inhabiting the chemocline of meromictic lakes.

The present work is a case study of the lake, for which we studied the profiles of physico-chemical characteristics during the period from July 2002 to March 2009 and tested the ability of the simplified 1D mathematical model to simulate the observed seasonal dynamics of temperature and salinity for the same period.

The main aim of this work is to collate and systemize data about the vertical structure of Lake Shira obtained in the process of routine monitoring from 2002 to 2009, to describe the nature of the lake's stratification, to explain the patterns of its yearto-year variations and to compare modeled and observed profiles of salinity. This has been done the first time for this lake. In all the previous major works (Kalacheva et al. 2002; Belolipetskii and Genova 2008; Rogozin et al. 2009), only profiles for certain dates were given. There are only a few systematic seasonal studies of meromictic salt lakes that freeze 
for long periods, especially for winter periods. As far as we know, there are no such investigations into the year-to-year variations of under-ice stratification for meromictic lakes. That is why the results of this work can add to the currently available knowledge about lakes of this type.

\section{Materials and methods}

\section{Lake description}

Lake Shira $(90.11 \mathrm{E}, 54.30 \mathrm{~N})$ is located in the northern part of the Republic of Khakassia, Siberia (Russian Federation). This elliptical $(9.3 \times 5.3 \mathrm{~km})$ lake has an area of $35.9 \mathrm{~km}^{2}$ and maximum depth of $23.8 \mathrm{~m}$ (2007-2009). The main inflow is from Son River that provides about $42 \%$ of fresh water supply to the lake; other sources of water are precipitation and seepage water. The lake has no outflow. The lake is ice-covered in most years from the end of November to the beginning of May.

The surface elevation of Lake Shira has noticeably changed over the whole period of observation. The lake's salinity changed inversely with changes in water volume (Krivosheev and Khasanov 1990) (Fig. 4). During the period from 1920s to 1930s, the lake's level decreased by $7 \mathrm{~m}$, which was caused by the decrease in the total amount of precipitation in the region. In this period, the salinity reached the maximum of $27 \mathrm{~g} \mathrm{l}^{-1}$ in 1926 (Kuskovsky, Krivosheev, 1989) (Fig. 4). The nature of the lake's stratification at that time is not known, and it is unclear whether the lake was meromictic or turned into a holomictic in some years.

Field measurements

Lake Shira was investigated on a seasonal basis from July 2002 to March 2009, except 2006 when only a summer survey was conducted. Data of 2006 were kindly provided by Dr. E. Zadereev and Dr. A. Tolomeev. As far as we know, there are no earlier annual studies on this lake. In the present work, under-ice surveys were conducted in the month of February during 2003, 2004, 2008 and in March during 2005, 2007, 2008 and 2009. For the years 2003, 2004 and 2005, the lake was surveyed in the end of May. In summer, the lake was surveyed every year from 2002 to 2009 during July and August, i.e., when it was stably stratified. The additional summer survey was conducted in June 2007. Autumnal profiles of 2003, 2004, 2007 and 2008 were measured at the end of October or beginning of November except in 2002 when the profiles were measured at the beginning of October. On most occasions, profiles were determined only once. All the dates of measurements are summarized in Fig. 3.

All water samples for measurements were taken at the same site (54.30.350 N, 90.11.350 E, GARMIN Olathe, Kansas, USA) at the central deepest part of the lake. Sampling as far as possible was done during calm weather, with the wave height not exceeding $5 \mathrm{~cm}$, from an anchored boat. For under-ice measurements, i.e., during winters, a hole was drilled in ice.

The vertical profiles of temperature, specific conductance, dissolved oxygen, turbidity and redoxpotential were measured simultaneously with Hydrolab Data-Sonde 4a (Hydrolab, Austin, Texas, USA) and YSI 6600 (Yellow Springs, Ohio, USA) submersible profilers. The position of the oxic-anoxic interface was assumed at the depth where the redoxpotential just changed from positive to negative with accuracy of about $20 \mathrm{~cm}$ except in May 2003 when we failed to measure the profiles deeper than $13 \mathrm{~m}$, as the profiler got out of order. Then the redox zone depth was detected on basis of sulfide and determined in the samples taken by the Ruttner sampler at 1-m intervals.

Sulfide was measured by Aquamerck kit (Merck, Germany). Conductivity readings at in situ temperatures $\left(C_{\mathrm{t}}\right)$ were standardized to specific conductance at $25^{\circ} \mathrm{C}$ using

Cond $=C_{\mathrm{t}} \times(1+0.0191 \times(T-25))^{-1}$

where $T$ is the in situ temperature in degrees centigrade (YSI).

The salinity was calculated as quadratic approximation of the dependence of ash content upon specific conductance measured for Lake Shira water in laboratory:

$$
S=-0.087 \text { cond }^{2}+4.4403 \text { cond }-37.16,
$$$$
R^{2}=0.95, n=19
$$

where $S$ is the salinity determined as ash content $\left(\mathrm{g} \mathrm{l}^{-1}\right)$, Cond is specific conductance at $25^{\circ} \mathrm{C}$ of the lake water samples $\left(\mathrm{mS} \mathrm{cm}^{-1}\right)$. Conductivity sensors were calibrated against $3 \mathrm{M} \mathrm{KCl}$ (Hydrolab, YSI), 
oxygen electrodes were calibrated against Winkler titration of Lake Shira water with Aquamerck kit (Merck, Germany). The calibrations were conducted before each survey.

\section{Environmental conditions}

We obtained the data on the timing of formation and disappearance of ice cover for the station located at Lake Shira shore from the Hydro-Meteorological Service of Russian Federation. The wind force, air temperature, cloudiness and humidity measured as often as four times a day were obtained from the weather archive of "Pogoda Rossii" ("Weather in Russia") site (http://meteo.infospace.ru/). The yearto-year variations of weather were assessed on the basis of cumulative temperature and wind amount over a 30-day period before ice formation (roughly corresponding to the period of autumn circulation) and 30day period after the disappearance of ice (roughly corresponding to the period of spring circulation). The four available daily values of temperature and wind force were summarized and then summarized for 30 days to compare between years (Fig. 2). Positive and negative temperatures were summed up separately to demonstrate the temperature variability in Fig. 2. The wind direction was not taken into account.

\section{Mathematical modeling}

To describe the profiles of water temperature, salinity and density in the central deepest part of the lake during an open-water period, we used a 1-D mathematical model (Belolipetskii and Genova 2008). The equation for the temperature is

$\frac{\partial \mathrm{T}}{\partial \mathrm{t}}=\frac{\partial}{\partial \mathrm{z}}\left(K_{\mathrm{T}} \frac{\partial \mathrm{T}}{\partial \mathrm{z}}\right)+\alpha \beta \frac{F_{\mathrm{I}} e^{-\beta z}}{c_{\mathrm{p}} \rho_{0}}$,

with the boundary conditions

$K_{\mathrm{T}} \frac{\partial \mathrm{T}}{\partial \mathrm{Z}}=-\frac{F_{\mathrm{n}}}{c_{\mathrm{p}} \rho_{0}} \quad z=0$,

$K_{\mathrm{T}} \frac{\partial \mathrm{T}}{\partial \mathrm{Z}}=-\frac{F_{\mathrm{n}}}{c_{\mathrm{p}} \rho_{0}} \quad z=H$.

Here, $T$ is the water temperature, $K_{\mathrm{T}}(z)$ is the coefficient of vertical turbulent mixing, $F_{\mathrm{H}}$ is the heat exchange with the bottom, $F_{\mathrm{n}}$ is the entire heat flow through the free surface, $F_{\mathrm{I}}$ is the incident short-wave radiation, $\beta$ is the radiation absorption coefficient, $\alpha$ is the parameter determining the portion of the radiation penetrating into deep water layers $(0 \leq \alpha \leq 1), c_{\mathrm{p}}$ is the specific heat capacity of the water, $\rho_{O}$ is the characteristic water density and $H$ is the lake depth.

The equation for salinity is formulated similarly:

$$
\begin{gathered}
\frac{\partial \mathrm{S}}{\partial \mathrm{t}}=\frac{\partial}{\partial \mathrm{z}}\left(K_{\mathrm{S}} \frac{\partial \mathrm{S}}{\partial \mathrm{z}}\right), \\
\left.K_{\mathrm{S}} \frac{\partial \mathrm{S}}{\partial \mathrm{z}}\right|_{z=0}=-F_{\mathrm{S}},\left.\quad K_{\mathrm{S}} \frac{\partial \mathrm{S}}{\partial \mathrm{z}}\right|_{z=H}=F_{\mathrm{SH}} .
\end{gathered}
$$

Here, $S$ is the water salinity, $K_{\mathrm{S}}(z)$ is the coefficient of vertical turbulent mixing for salinity, $F_{\mathrm{SH}}$ is the mass exchange with the bottom and $F_{\mathrm{S}}$ is the flow through the free surface. It is also necessary to set the initial distributions of the temperature and salinity: $T(0, z)=T^{0}(z), \quad S(0, z)=S^{0}(z)$.

Density was calculated using Boussinesq approximation for Lake Shira water:

$\rho=\rho_{0}\left(\varepsilon_{1}+\varepsilon_{2} \frac{T}{T_{0}}+\varepsilon_{3} \frac{S}{S_{0}}\right)$,

where $\rho_{0}=1.0254 \mathrm{~g} / \mathrm{cm}^{3}, \quad \varepsilon_{1}=0.984522 ; \quad \varepsilon_{2}=$ $-0.00712 ; \varepsilon_{3}=0.041124, T_{0}=17.5^{\circ} \mathrm{C}, S_{\mathrm{o}}=35 \%$.

For winter, $\varepsilon_{1}=0.9825$ and $\varepsilon_{2}=-0.0015$. For the subglacial period, we used a simplified model of ice formation based on the single-phase Stefan problem with the linear temperature distribution in solid phase. We isolated an under-ice convective mixing layer, which was formed as a result of the increased salinity during ice formation. To obtain analytical solutions concerning the vertical distributions of temperature, we used a vertical structure diagram in the form of several layers (Belolipetskii and Genova 2008).

\section{Results}

Physical-chemical profiles

The lake was chemically stratified during all the study period from 2002 to 2009 . The seasonal change in the measured profiles was qualitatively similar for all years. We illustrate only typical examples for 3 years (Fig. 1). During autumn periods, the temperature, salinity (measured on the basis/as a function of conductivity) and oxygen were distributed evenly throughout the depth profile from surface to the maximum salinity and temperature gradients $Z_{m}$ (see October 2002, November 2003, 2004 on Fig. 1). The uniform parts of profiles indicated the layer of 
mixing, i.e., the thickness of mixolimnion. The dates of ice cover formation ranged from November 11 in 2003 to November 30 in 2002 . We did not measure the water temperature immediately after ice formation, but as deduced it from the available values of under-ice water, the freezing point of water was about $-0.7^{\circ} \mathrm{C}$. In all winters except in 2004 , the base of mixolimnion $\mathrm{Z}_{\mathrm{m}}$ migrated deeper than in autumn (compare autumn-winter profiles of 2003-2004 with the ones of 2002-2003, 2004-2005, Fig. 1). Consequently, due to mixing with deeper, higher salinity layers, the salinity in the winter mixolimnion increased compared with the autumn. In winter, the mixolimnetic oxygen concentration varied between 8 and $12 \mathrm{mg}^{-1}$, and it was almost evenly distributed throughout the mixolimnion (Fig. 1). The ice thickness varied from $63 \mathrm{~cm}$ in March 2005 to $102 \mathrm{~cm}$ in March 2009, and the ice salinity was near $2.6 \mathrm{~g}^{-1}$ (estimated in 2004 and 2007 as salinity of water from completely thawed ice samples). During all winters except in 2003-2004, the oxic-anoxic interface was observed at the lower boundary of mixolimnion $\mathrm{Z}_{\mathrm{m}}$ (February 2003 and March 2005, Fig. 1). The date of complete disappearance of ice varied from May 19 in 2003 to April 30 in 2007. In May 2003 and May 2004, the salinity in the upper 2$\mathrm{m}$ layer decreased drastically due to melting of ice. Therefore, the second halocline, represented by the maximum salinity gradient $Z_{\mathrm{E}}$, was formed in the near-surface layers of mixolimnion (Fig. 1). The depth of $Z_{E}$ coincided with the thermocline and pycnocline, indicating the formation of a warm
Fig. 1 Seasonal dynamics of Lake Shira stratification. Gray color indicates sulfide-containing water.* In May 2003, profiles were measured only to $13 \mathrm{~m}$ (see "Materials and Methods")

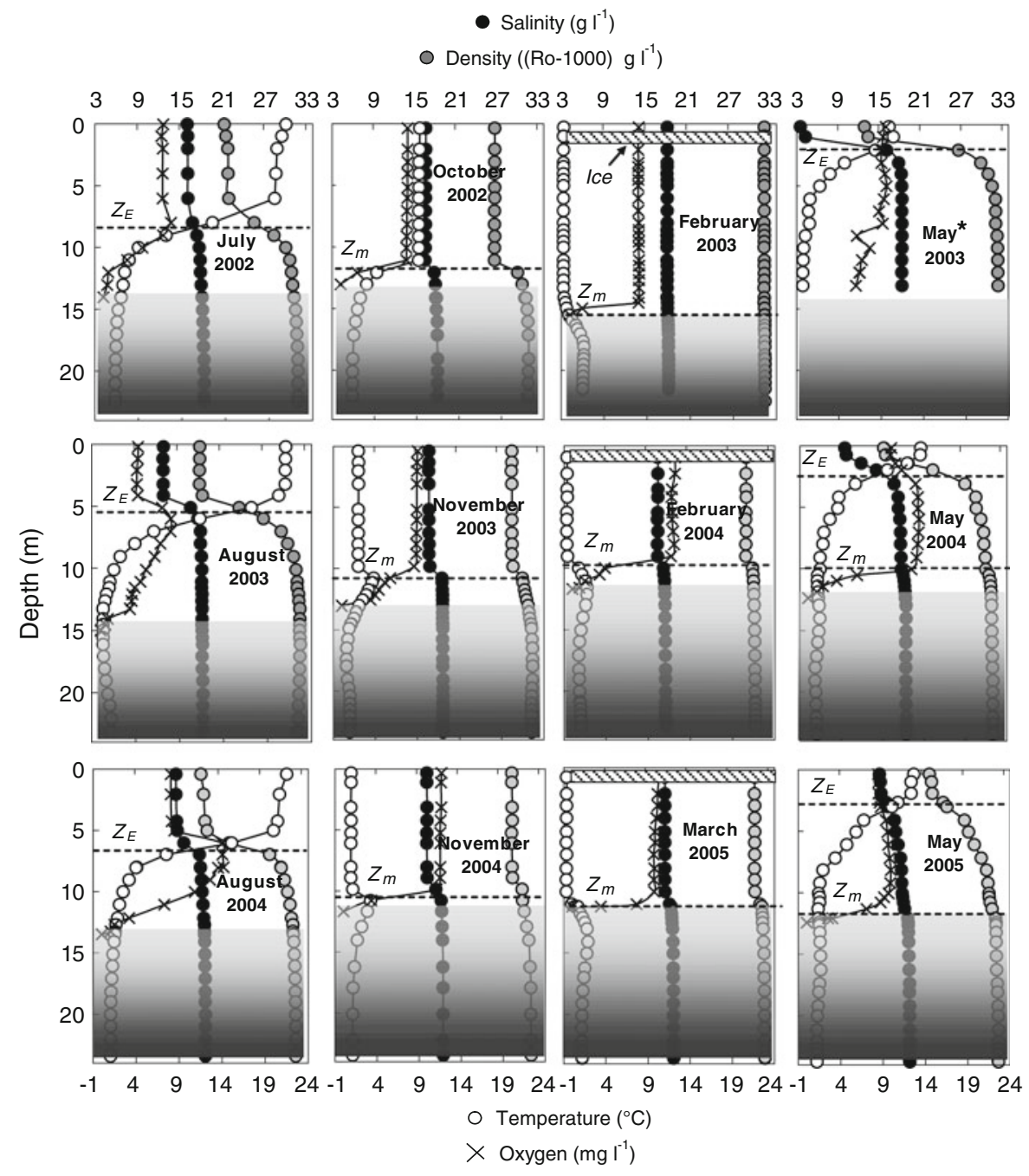


epilimnion (Fig. 1). The former halocline, as well as the oxic-anoxic interface, remained near the previous mixolimnion depth (Fig. 1).

The stable summer stratification formed in June or beginning of July (data not shown), and the lower boundary of epilimnion, i.e., the top of thermocline, descended to the 5-6 m stratum (Fig. 1). During July and August, the position of thermocline was almost constant (data not shown). The point $\mathrm{Z}_{\mathrm{m}}$ became almost indistinguishable in the summer profiles. In the summer of 2007, the thermocline formed at ca. $11 \mathrm{~m}$ depth. The near-bottom temperature and salinity (1.0$1.9^{\circ} \mathrm{C}$ and 17.7-19.2 $\mathrm{g}^{-1}$ ) remained almost constant compared with upper layers for the entire period of the study, indicating the lake's meromixis. Water layers below the $Z_{m}$ depth were always anaerobic (Fig. 1), and the concentration of sulfide varied from 0.6 to $1.2 \mathrm{mM}$ near the bottom (Rogozin et al. 2009).

Even though the annual behavior of the measured profiles was qualitatively similar, the thickness of the winter mixolimnion differed noticeably from winter to winter. In 2003, 2008 and 2009, the winter depth of lower boundary of mixolimnion was $15.5,16.2$ and $16.7 \mathrm{~m}$, respectively; in contrast, in other winters, this depth ranged from 9.5 to $12.5 \mathrm{~m}$.
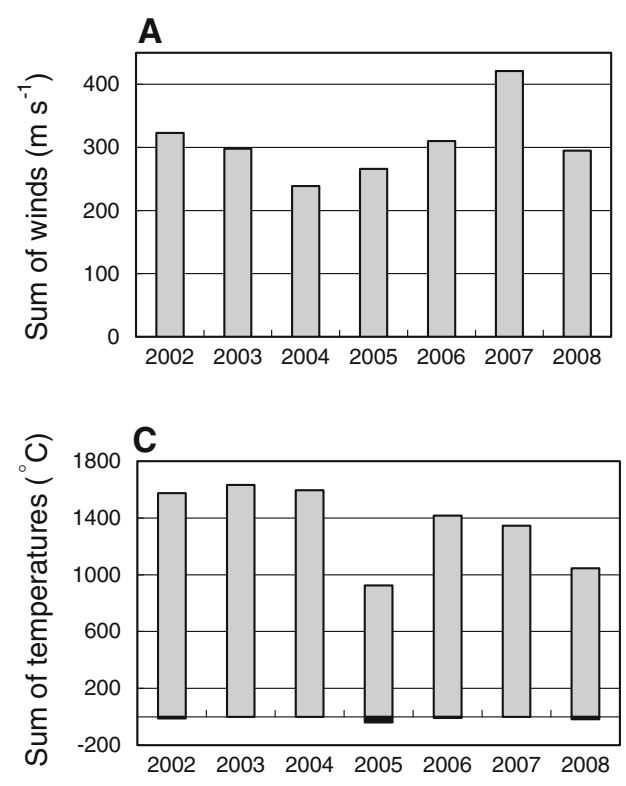

Fig. 2 Weather conditions at Lake Shira region during periods of spring and autumn overturn. a Sum of winds for 30-day period after ice cover disappearance; b Sum of winds for 30day period before ice cover formation; c Sum of temperatures
Meteorological conditions

We investigated the annual variations of wind and temperature conditions roughly from the time when epilimnion was formed in the spring to that when mixolimnion was formed in autumn. Throughout this study on the lake, the 30-day period after ice clearance was significantly more windy than the 30 day period before ice formation (Fig $2 \mathrm{a}, \mathrm{b}$ ). The spring period of 2007 was anomalously windy, with a wind velocity that was about $30 \%$ higher than is usual for this period (Fig 2a). The autumn period in 2008 was the windiest and the spring of 2005, the coldest and that of 2003, the warmest. The autumn periods in 2002 and 2003 were relatively the coldest, and that in 2006, the warmest (Fig. 2d).

Modeling of temperature and salinity profiles

The calculated and measured profiles were similar for most dates. We used the depth of turbulent mixing layer as an indicator of the calculated and observed mixing patterns (Fig. 3). Obviously, the turbulent mixing layer always spread downward to the upper
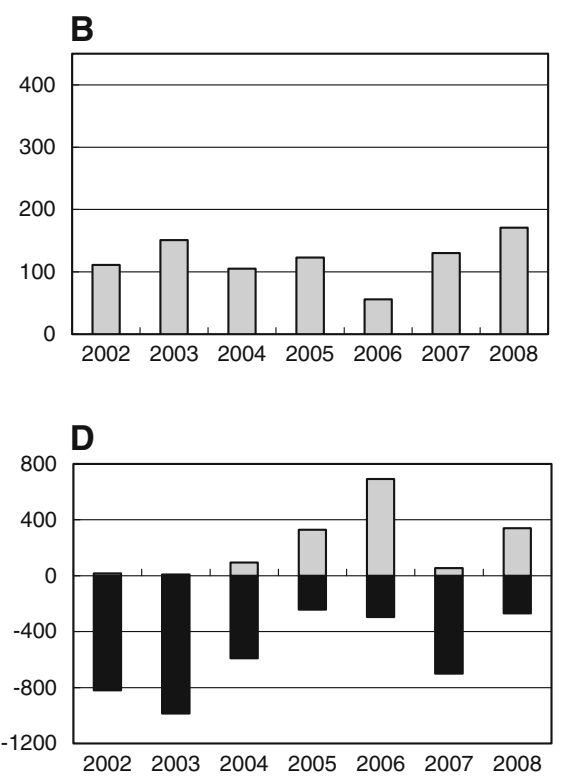

for 30-day period after ice cover disappearance; d Sum of temperatures for 30-day period before ice cover formation; gray columns indicate sums of positive temperatures; black columns indicate sums of negative temperatures 
boundary of the pycnocline, i.e., to the depth of maximal salinity gradient. Hence, it was positioned near $\mathrm{Z}_{E}$ during the warm period and gradually descended to $\mathrm{Z}_{\mathrm{m}}$ during cooling, autumnal mixing and winter stratification. Therefore, the sharp maxima indicate the moments of ice melting and formation of thermocline in the upper layer (Fig. 3). The "shoulders" of solid lines indicate the calculated thermocline position during the stable summer stratification and lateral straight portions the calculated winter mixolimnions.

The measured profiles marked the initial conditions at the start of each simulation. Every simulated year was launched from the earliest date of the year for which the open-water field measurements were available and concluded on the calculated date of ice cover formation of the following year. Therefore, the summer and autumnal profiles for all years, except 2002 and 2009, were simulated twice: first, at the end of the previous simulated "year" and secondly, at the start of the current "year". The respective overlapping parts of the calculated curves coincided well with each other, except in 2007 (Fig. 3). In 2007, the observed thermocline position was exceptionally deep. The calculated thermocline position was also deeper than for the other simulated "years" although it was "shallower" than the depth actually observed (Fig. 3). If the calculation was initiated using the measured profiles of June 2007, the calculated position of thermocline and calculated autumnal depth of turbulent mixing layer were closer to the observed depths more correct. In 2008, nevertheless, the calculated under-ice mixolimnion position was considerably "shallower" than the observed one (Fig. 3).

The calculated depths of winter mixolimnions were in good accord with the observed ones for the winters of both 2002-2003 and 2004-2005. We did not measure profiles for the winter of 2005-2006. In other winters, agreement between the measured and calculated profiles was not so good. The calculated depths for the descent of winter mixolimnions in 2002-2003, 2007-2008 and 2008-2009 were "shallower" than the observed ones (Fig. 3).

\section{Discussion}

Generally, this study contains the first proof that Lake Shira is meromictic, as evidenced by the year-to-year observations on the lake's temperature cycle, salinity, ice formation, etc. Earlier, short-term studies and data analyses by different investigators on Lake Shira (Kalacheva et al. 2002; Rogozin et al. 2009) also confirm our present findings based on long-term data analyses as well as simulation studies. Based on our present results, the rough pattern of the lake's mixing behavior is as follows. The monimolimnion does not mix at all, whereas mixolimnion mixes in autumn from the surface to the lower boundary, which depth
Fig. 3 a Depth of maximal gradient of salinity: calculated for odd years (solid line), the same for even years (gray line); measured (filled triangle); sharp maxima indicate the moments of ice melting and formation of thermocline in the upper layer; $\mathbf{b}$ Depth of observed oxic-anoxic interface (open triangle). Arrows indicate "deep" mixolimnions

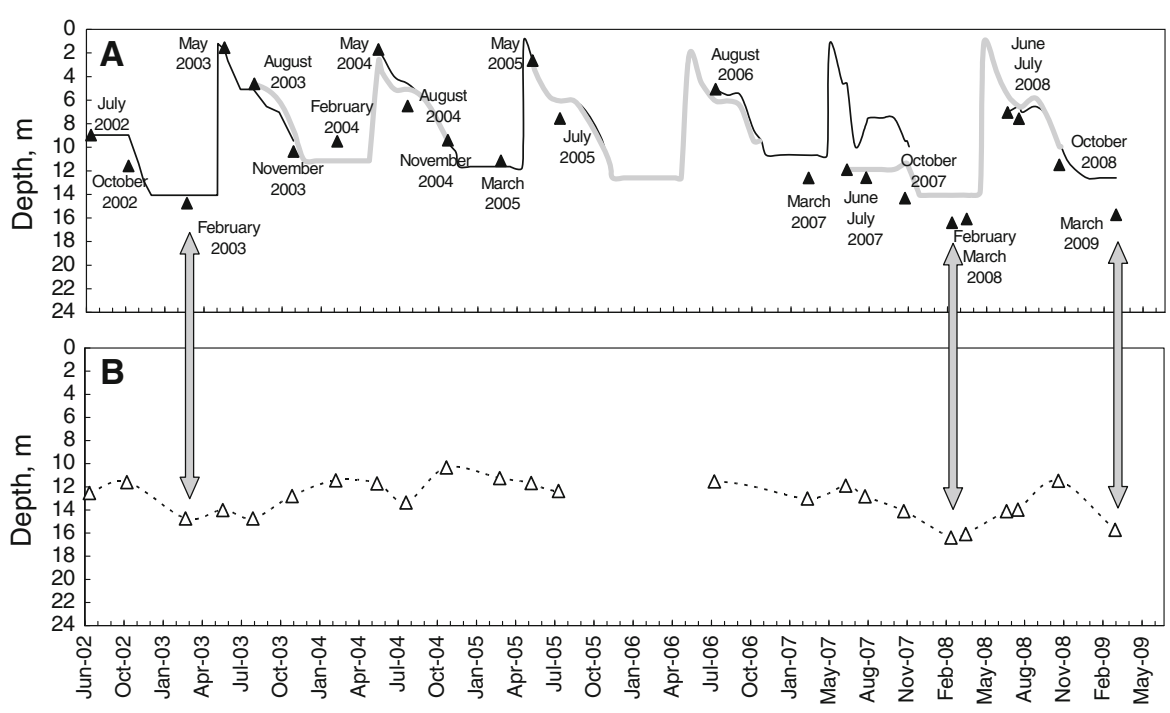


position is annually variable. The thickness of mixolimnion depends on weather conditions and can be roughly predicted with one-dimensional mathematical model.

\section{Mixing behavior of Lake Shira}

Evidently, in deep saline lakes that tend to have ice cover in winter, after ice melt, a layer of relatively fresh water must protect the stratification below and inhibit deep mixing. For example, this mechanism was present in saline lakes in Saskatchewan, Canada (Hammer 1994). Since no even distributions were observed on spring mixolimnetic profiles, one can assume that no spring overturn of mixolimnion took place in Lake Shira. Obviously, from the very beginning of the open-water period, the low-saline upper water divided the mixolimnion into epilimnion and aerobic hypolimnion, so the deepening of epilimnion took place simultaneously with the formation of summer stratification.

In contrast, even mixolimnetic profiles observed in late autumn give evidence of autumnal mixolimnetic circulation from surface to upper boundary of monimolimnion. In many meromictic lakes, deep recirculation erodes the monimolimnion, leaving a sharp gradient at the end of the circulation period. (Boehrer and Schulze 2008). This gradient is sharper than at the start of circulation, so the transition of all water properties (temperature, salinity, redox-potential, etc.) happens within a few decimeters from mixolimnetic values to monimolimnetic values (Boehrer and Schulze 2008). In Lake Shira, sharp gradients are also observed at the lower boundary of mixolimnion during the period of autumn mixing and winter stratification (Fig. 1). Our results show that in terms of mixing behavior, Lake Shira can be termed as a typical meromictic lake with autumnal formation of mixolimnion. During autumnal circulation, the water temperature decreases from summer epilimnetic value (about $+20^{\circ} \mathrm{C}$ ) to freezing point (about $-0.7^{\circ} \mathrm{C}$ ) contemporary with broadening of mixolimnion (Fig. 1). Lake Shira's water reaches its maximal density near the temperatures $+1^{\circ} \mathrm{C}$ to $+1.5^{\circ} \mathrm{C}$ as we estimated once in thermostat by densitometer for water of $18 \mathrm{~g} \mathrm{l}^{-1}$ salinity (sample taken on March 2007). The annual near-bottom values of temperature and salinity confirm this estimation (Fig. 1).
Therefore, under the temperatures of about $+1^{\circ} \mathrm{C}$ to $+1.5^{\circ} \mathrm{C}$, the water column of mixolimnion has lowest stability, and the wind-induced circulation should be most intensive.

The freezing raised salinity of water layers below the ice by the exclusion of brine from the ice formed (Fig. 1). The maximum recirculation depth seems to be reached when the lake is covered with ice and the raised salinity in the upper layers tends the water to sink. This mechanism has also been reported for the saline lakes in Saskatchewan, Canada (Hammer 1994).

The stratification patterns observed from year to year in last period in Lake Shira, i.e., the varying thickness of mixolimnion, reveals unstability of the lake system. Therefore, it was important to understand the causes of year-to-year variations in depth of $\mathrm{Z}_{\mathrm{E}}$ and $\mathrm{Z}_{\mathrm{m}}$ observed during stable summer and winter stratification conditions. Obviously, meteorological conditions, mainly winds and air temperature, have important influence on turbulent mixing processes. Mixing process, in its turn, depends on the how stable are the preceding stratification in both summer and winter ones.

Influence of meteorological conditions

The available data are obviously insufficient for the statistical analysis of the effect of weather conditions on the stratification of Lake Shira, but some suggestions can be made. We suggest that the exceptionally thick epilimnion (hence "deep" thermocline) detected in the summer of 2007 was caused by the preceding windy spring period. In nearly all lakes, wind is the controlling factor for the thickness of the epilimnion (Boehrer and Schulze 2008). The 30-day period after ice disappearance in 2007 was noticeably windiest compared with other years (Fig. 2). In summer 2002, the relatively thick epilimnion may also be explained by the relatively windy spring although not so evident (Fig. 2). In contrast, the influence of spring temperature on deepening of thermocline is not evident from the available data. Indeed, neither spring 2002 nor spring 2007 was colder than other springs (Fig. 2).

Since wind and temperature conditions in the late autumn of 2002 and 2007 were normal rather than anomalous, the "deep" winter mixolimnions of subsequent years, 2003 and 2008, cannot be 
unambiguously related to wind or temperature influence in late autumn (Fig. 2b, d).

In autumns, the influence of wind and temperature on circulation is not evident from the available data because, for example, the late autumn of 2003 was the coldest and relatively windy (Fig $2 b$ ), whereas the mixolimnion in 2004 was not "deep" but, on the contrary, the shallowest of all (Fig. 1). Nevertheless, in Lake Lugano (Switzerland), two consecutive cold and windy winters (2004-2005 and 2005-2006) destabilized the water column and led to two exceptionally strong mixing events (Holzner et al. 2009).

\section{Adequacy of the model}

Since the calculated and observed profiles corresponded with one an other, the simplified onedimensional model is applicable to describe salinity and density profiles as well as mixing behavior of Lake Shira. The model adequately simulates the lake for the period 2002-2005, but not for 2007-2009. The calculated thermocline in summer 2007 and mixolimnions in 2008 and 2009 were well "shallower" than observed ones (Fig. 3a). The effects of internal currents, wind directions and lake morphology cannot be explained by the one-dimensional model. We, therefore, presuppose that the 2-D and 3$\mathrm{D}$ models are more adequate for lake dynamics prognoses. In addition, the available data of wind force are based on four fixed time measurements per day, but the strong transient storms as observed in spring 2007 will produce noticeable mixing effects between the periods wind force measurements.

\section{Influence of starting profiles}

Profiles of stable summer stratification may be considered as "initial" conditions for the autumnal mixing processes. Notably, the "deep" winter mixolimnions of 2003 and 2008 were observed for the years when summer epilimnion in preceding years was also "deep" (Fig. 3), except 2008-2009. Simulations demonstrate a similar tendency (Fig. 3). Thus, the depth of the autumnal mixing layer seems to depend not only on weather conditions but also on thickness of epilimnion in summer: the deeper the thermocline is in summer thermocline position, the deeper will be mixolimnion in winter. For example, we simulated the lake profiles for meteorological conditions of the summer-autumnal period of 2007, but starting from profiles of summer 2005 when epilimnion was ca. $2 \mathrm{~m}$ shallower than in 2007. Consequently, the calculated autumn mixolimnion was also $2 \mathrm{~m}$ "shallower" than that calculated from the starting profiles of 2007 (data not shown). In contrast to the autumnal mixing, the effect of the starting profiles on spring mixing processes and summer stratification was not evident because the mixing always started from the homothermal profiles formed during the previous winter. Nevertheless, year-to-year difference in starting conditions in spring may be caused by the difference of ice thickness and salinity in mixolimnion.

Generally, both the model simulation and simple analysis of meteorological conditions and starting profiles have demonstrated the effect of spring winds on mixolimnion "deepening" for the open-water period of 2007-2008.

\section{Position of oxic-anoxic interface}

The positioning of oxic-anoxic interface in lakes with sulfide-containing monimolimnions, such as Lake Shira is particularly important as it gives an insight into the causal mechanisms. In lakes such as L. Shira, the zones of transition from aerobic water layers to anaerobic ones (the chemocline, the redox zone) are usually characterized by increased activity of planktonic communities (Jorgensen et al. 1979; Van Gemerden and Mas 1995; Overmann 1997); hence, there are significant flows of carbon and nutrients in this region. Light is invariably a limiting factor for anoxic phototrophic bacteria, which perform photo-oxidation of sulfide in deep chemoclines of stratified lakes (Van Gemerden and Mas 1995; Overmann 1997). The rate of sulfide photo-oxidation obviously depends on the light level and, hence, on the depth position of chemocline. Moreover, it has been shown that both the intensity and spectral composition of the light penetrating into the redox zone determine the species composition of the phototrophic bacterial community (Montesinos et al. 1983). A change in these light conditions can trigger a change in the species composition of phototrophic bacteria (Tonolla et al. 2005). Increases in phytoplankton biomass caused by the inflow of nutrients from the monimolimnion, due to disturbance or weakening of meromictic conditions, has also been 
reported for several lakes (Melack and Jellison 1998; Tonolla et al. 2005; Simona 2003). Similar events may hypothetically occur in other stratified lakes, including Lake Shira, suggesting the importance of changes in water density for predicting stratification and its stability.

The vertical distribution of hydrogen sulfide in lakes is certainly determined by the rates of sulfide production (bacterial sulfate reduction), its chemical and biological oxidation and transfer, which depend on the turbulence. Generally, calculation of the profile of sulphide concentration should take into account all the above-mentioned processes. However, in Lake Shira, the observed changes with depth of redox from positive to negative values in winter corresponds to the lower boundary of mixolimnion base (Fig. 1,3). This overlap of the two implies that the vertical coordinate of the redox change in Lake Shira is largely determined by the meteorological and hydrophysical factors. Therefore, generally the adequate prognosis of mixolimnion depth is sufficient for the prediction of the oxic-anoxic interface position in winter in Lake Shira. Recently, Rogozin et al. (2009) showed that in Lake Shira, the light intensity and biomass of purple sulfur bacteria in winter exceeded the summer values, due to the increased transparency of mixolimnion in winter. Both high chemocline position and absence of snow also contributed to this. It seems, therefore, that the ice-period was not a "dead" season with respect to photosynthetic production of anoxic phototrophic bacteria. This implies prediction chemocline position in winter is important.

Finally, we showed that the position of chemocline in Lake Shira in most years can be predicted by modeling of mixing processes only, without taking biochemical processes into account. In contrast, since in spring and summer, the thermal stratification of mixolimnion prevents turbulent mixing of deeper waters, the chemocline position may be affected by other factors, such as microbial activity and internal hydrodynamical processes. These processes are seishes, internal waves and horizontal flows induced by intrusions from boundary mixing and by differences between rates of heating and cooling and wind mixing between the pelagic and littoral zone, etc. (MacIntyre and Jellison 2001). It should be noted that the summer position of the oxic-anoxic interface will be relatively "deep" as in 2003, 2008 and 2009, because of "deep" mixolimnions in the preceding winters. It suggests that the summer oxic-anoxic interface "remembered" its previous winter position to some extent.

\section{Origin of Lake Shira meromixis}

Good understanding of stratification is required not only to predict the future of our lakes under the probable climate change, but also to better interpret the past from lacustrine sediment cores (Brauer 2004). The aim of such interpretations is not only to document the lake's history, but also to comprehend the climate changes in the past, namely, by relating variations of the lake sediments to circulation patterns in the lakes and finally to the climatic conditions that trigger such changes (Boehrer and Schulze 2008).

We believe that the lake's meromixis, according to the generally accepted Hutchinson's classification of lake stratification (Hutchinson 1957), have an ectogenic (i.e., induced by spread of fresh water above mineralized water) rather than a crenogenic (i.e., induced by supply of higher mineralized water from the bottom) origin. Salinity of around $27 \mathrm{gl}^{-1}$ measured during the period of the lowest lake level in 1926 (Kuskovsky and Krivosheev 1989) is in good agreement with the calculated salinity estimates by us based on the lake's water volume shrinkage and assuming that the total amount of dissolved salts present in the lake is constant (Fig. 4). Nevertheless, salinity values observed before 1910 were higher than calculated ones (Fig. 4). Therefore, some processes of salt transformation, for example precipitation, could probably take place at the period of shrinkage in 1920-1930s. A sharp 4-meter raise of the lake level over 10 years observed after the shrinkage was caused by an increased amount of precipitation from ca. $220 \mathrm{~mm} \mathrm{year}^{-1}$ in 1920-1925 to maximum of $380 \mathrm{~mm} \mathrm{year}^{-1}$ in 1940 (Krivosheev and Khasanov 1990). A considerable inflow of water due to superficial runoff during this period probably contributed to the formation of the stable salinity gradient observed at present. Melack and Jellison (1998) and Hammer (1994) have described similar cases for Lake Mono in the US (Melack, Jellison, 1998) and a group of Saskatchewan lakes in Canada, respectively (Hammer 1994). In addition, it is now well known that endogenic process of freezing out of salts from the upper water layers meters during ice formation as well as precipitation of sodium sulfate 

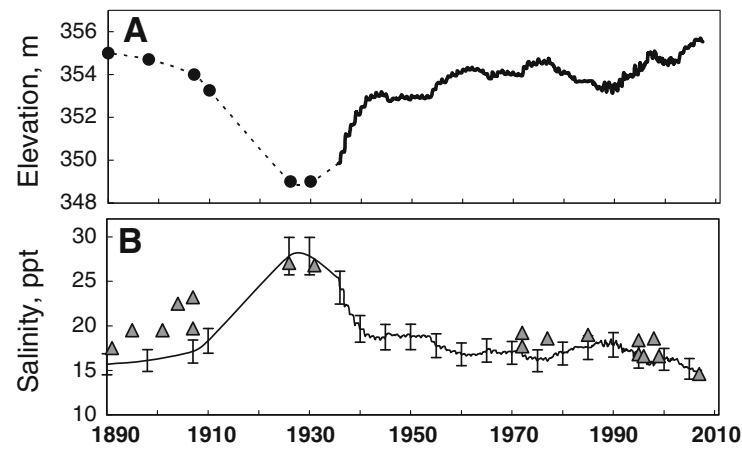

Fig. 4 Surface elevation and salinity of Lake Shira: a surface elevation ASL: (thick solid line) measured by meteoservice (1936-2007); (filled circle)—previously reported (Krivosheev and Khasanov 1990); b salinity: (thin solid line) average salinity calculated according to estimates of volume change; (filled triangle) - previously reported (Krivosheev and Khasanov 1990; Kuskovsky and Krivosheev 1989; Kalacheva et al. 2002; Parnachev et al. 2002) and measured for 2009 (this paper)

during autumn cooling also promote meromixis (Hammer 1994). Both these endogenic processes leading to an increase in salinity of upper layers, and their eventual sinking seem to contribute to Lake Shira's meromixis. A more detailed investigation into the mechanisms that stabilize and preserve the lake's meromixis may provide the exact information on the chronology of events that sustain the meromixis in the lake, including the role of certain ectogenic processes. This would mean conducting the chemical analysis of brine formed during ice formation and performing model calculations. Such studies are although outside of the framework of this paper, are in progress (Rogozin et al., in preparation).

\section{Conclusions}

1. Based on the period of 2002-2009, Lake Shira is meromictic with autumnal overturn of mixolimnion. The depth of mixolimnion is variable, depending on a year.

2. The exceptionally windy spring conditions as in 2007 cause the deepening of thermocline in summer and consequent deepening of mixolimnion in the ensuing winter.

3. A simplified one-dimensional model can be applied to roughly describe salinity and density profiles and mixing behavior of Lake Shira.
4. Spring mixing processes contribute to the autumnal formation and positioning of mixolimnion.

5. The winter position of the oxic-anoxic interface is determined by mixing processes.

Acknowledgments We thank Mr. Fyodor Kozlov for assistance in winter lake surveys, Dr. Alexander Tolomeev and Dr. Egor Zadereev (Institute of Biophysics SD RAS) for field data of August 2006, Dr. Galina Kalacheva (Institute of Biophysics SD RAS) for ash content determination and all others who helped us in expeditions. We are also very grateful to Dr. Wolf Mooij (Netherlands Institute of Ecology) and two anonymous reviewers for valuable comments and advice on article preparation. This work was partly supported by the Netherlands Organization for Scientific Research, Grant 047.011.2004.030, the Russian Foundation for Basic Research, Grants No. 09-04-01114-a and 09-05-00915-a, by Siberian Branch of Russian Academy of Sciences, Integrative Project No. 95 and joint Taiwan-Siberian Project No. 149, by Russian Academy of Sciences, Program No. 23.15, by award No. PG07-002-1 of the Ministry of Education and Sciences of Russian Federation and U.S. Civilian Research \& Development Foundation for the Independent States of the Former Soviet Union (CRDF).

Open Access This article is distributed under the terms of the Creative Commons Attribution Noncommercial License which permits any noncommercial use, distribution, and reproduction in any medium, provided the original author(s) and source are credited.

\section{References}

Belolipetskii VM and Genova SN (2008) Calculation of vertical profiles of temperature and salinity in Shira Lake. Computational Technologies Vol.13. The Bulletin of KazNU (Mathematics, mechanics and informatics issue) No. 3 (58).- - joint edition, Part 1: 261-266 (in Russian)

Boehrer B, Schulze M. (2008) Stratification of lakes Reviews of Geophysics 46, RG2005, doi:10.1029/2006RG000210

Brauer A (2004) Annually laminated lake sediments and their paleoclimatic relevance. In: Fisher $\mathrm{H}$ et al (eds) Climate in historical time: towards a synthesis of holocene proxy data and climate models. Springer, Heidelberg, Germany, pp 108-128

Brocks JJ, Schaeffer P (2008) Okenane, a biomarker for purple sulfur bacteria (Chromatiaceae), and other new carotenoid derivatives from the 1640 Ma Barney Creek Formation. Geochim Cosmochim Acta 72(5):1396-1414

Degermendzhy AG, Belolipetsky VM, Zotina TA, Gulati RD (2002) Formation of vertical heterogeneity in the Lake Shira ecosystem: the biological mechanisms and mathematical model. Aquat Ecol 36:271-297

Hammer UT (1994) Life and times of 5 Saskatchewan saline meromictic lakes. Internationale revue der gesamten hydrobiology 79(2):235-248 
Holzner CP, Aeschbach-Hertig W, Simona M, Veronesi M, Imboden DM, Kipfer R (2009) Exceptional mixing events in meromictic Lake Lugano (Switzerland/Italy), studied using environmental tracers. Limnol Oceanogr 54:11131124

Hutchinson GE (1957) A treatise on limnology, vol. 1. Geography. Physics and Chemistry, John Wiley, New York

Jorgensen BB, Kuenen JG, Cohen Y (1979) Microbial transformations of sulfur compounds in a stratified lake (Solar Lake, Sinai). Limnol Oceanogr 24:799-822

Kalacheva GS, Gubanov VG, Gribovskaya IV, Gladchenko IA, Zinenko GK, Savitsky SV (2002) Chemical analysis of Lake Shira water (1997-2000). Aquat Ecol 36(2):123-141

Krivosheev AS, Khasanov AP (1990) Therapeutic lakes of Krasnoyarsk region. Krasnoyarsk Publishing House (In Russian)

Kuskovsky VS, Krivosheev AS (1989) Mineral lakes of Siberia. Nauka, Novosibirsk (in Russian)

MacIntyre S, Jellison R (2001) Nutrient fluxes from upwelling and enhanced turbulence at the top of the pycnocline in Mono Lake, California. Hydrobiologia 466:13-29

Melack JM, Jellison R (1998) Limnological conditions in Mono Lake: contrasting monomixis and meromixis in the 1990s. Hydrobiologia 384:21-39

Montesinos E, Geurrero R, Abella C, Esteve I (1983) Ecology and physiology of the competition for light between Chlorobium limicola and Chlorobium phaeobacteroides in natural habitats. Appl Environ Microbiol 46:1007-1016

Overmann J (1997) Mahoney Lake: a case study of the ecological significance of phototrophic sulfur bacteria. In: Jones (ed) Advances in microbial ecology. 15: 251-288

Overmann J, Sandmann G, Hall KJ, Northcote TG (1993) Fossil carotenoids and paleolimnology of meromictic Mahoney Lake, British Columbia, Canada. Aquatic Sciences 55(1)

Parnachev VP, Vishnevezky II, Makarenko NA, Petrov AI, Kopilova JG, Smetanina OV, Karnachuk OV, Turov YP, Klopotova NG, Djabarova NK, Banks D, Berezovsky AJ (2002) Natural waters of Shira district in Khakass republic/Edited by VP Parnachev. Tomsk State University, Tomsk. p 183 (In Russian)
Romero JR, Melack JM (1996) Sensitivity of vertical mixing in a large saline lake to variations in runoff. Limnol Oceanogr 41:955-965

Rogozin DY, Pimenov NV, Kosolapov DB, Chan'kovskaya JV, Degermendzhy AG (2005) Thin-layer vertical distributions of purple sulphur bacteria in chemocline zones of meromictic Lakes Shira and Shunet (Khakassia). Doklady Biological Sciences (Proceedings of the Russian Academy of Sciences) 400:54-56 (Translated from Doklady Akademii Nauk (2005) 400:426-429)

Rogozin DY, Zykov VV, Chernetsky MY, Degermendzhy AG, Gulati RD (2009) Effect of winter conditions on distributions of anoxic phototrophic bacteria in two meromictic lakes in Siberia, Russia. Aquat Ecol 43(3):661-672. doi: 10.1007/s10452-009-9270-7

Rogozin DY, Trusova MY, Khromechek EB, Degermendzhy AG (2010) Microbial community of the chemocline of meromictic Lake Shunet during summer stratification. Microbiology (Translated from Mikrobiologiya) 79(2): 253-261. doi:10.1134/S0026261710020189

Simona M (2003) Winter and spring mixing depths affect the trophic status and composition of phytoplankton in the northern meromictic basin of Lake Lugano. J Limnol 62:190-206

Sorokin YI (1970) Interrelations between sulfur and carbon turnover in a meromictic lake. Arch Hydrobiol 66:391446

Tonolla M, Peduzzi R, Hahn D (2005) Long-term population dynamics of phototrophic sulfur bacteria in the chemocline of Lake Cadagno, Switzerland. Appl Environ Microbiol 71:3544-3550

Van Gemerden H, Mas J (1995) Ecology of phototrophic sulfur bacteria. In: Blankenship RE, Madigan MT, Bauer CE (eds) Anoxygenic photosynthetic bacteria. Kluwer Academic Publishers, The Netherlands, pp 49-85

Zamana LV, Borzenko SV (2007) Hydrogen sulfide and other reduced forms of sulfur in oxic waters of Lake Doroninskoe, eastern Transbaikalia Doklady earth sciences (Proceedings of the Russian Academy of Sciences) 417: 1268-1271 (Translated from Doklady Akademii Nauk) 